\title{
66
}

\section{Email Reducing Stress for Student Teachers}

\author{
Bruce White and Rosie Le Cornu \\ School of Education, University of South Australia, Adelaide, Australia \\ Bruce.White@unisa.edu.au
}

Keywords: teacher education, electronic communication, research

\begin{abstract}
This paper reports on one aspect of a study which investigated the use of email between student teachers and university lecturers during the final practicum experience in a four year Bachelor of Education pre-service primary teaching course. The paper explores how the nature of electronic communication, together with the students' perceptions of 'university supervision' and their place in the school setting, affected the level of stress experienced by the student teachers in their placements. Student teacher stress has been reported in the literature as one factor which impedes student teacher learning during the practicum (Zeichner 1980). We argue that ICT has the potential to maximise student teachers' learning outcomes in the practicum by giving them more control over the learning process, reducing their stress, and enabling them to manage their practicum experience more effectively.
\end{abstract}

\section{INTRODUCTION}

The current context of higher education in Australia is characterised by reduction in government funding, strong competition amongst universities for students, and high staff-student ratios within many university programs. In addition, universities are being called to account for ensuring high levels of student learning outcomes while at the same time being asked to do so in increasingly more cost effective ways. These trends impact on the fieldbased components of pre-service teacher education programs (practicum), which traditionally have been costly in both time and money, but, as widely 
reported in the literature (Britzman 1991) seen by both students and educators as playing a critical role in pre-service teacher education.

Within this context, there has, at the same time, been an increasing focus on the use of ICT within the higher education sector. Much of this focus has been to support subject delivery for campus based courses and much has been written about the challenge of academics teaching 'on-line'. However, there has been much less written in regard to the practicum and ICT. It is only very recently that we are starting to read descriptions of its use, discussions about its value in the practicum and research into aspects of its application (Schlagal, Trathen and Blanton 1996, Wentworth, Monroe, Orme and Lynes 1999).

This paper reports on a study that investigated the use of email between student teachers and university lecturers during the final practicum experience in a four year Bachelor of Education pre-service primary teaching course.

\section{BACKGROUND}

The students involved in this study were enrolled in their final practicum subject, during which time the students had an on-campus component for ten weeks followed by a four weeks practicum. Each university lecturer teaching in the subject had a workshop group of about 27 students, with whom they worked in the structured on-campus program and then were responsible for them when they went into the practicum. The university lecturer's role was to support the student teachers in their schools via email and to support the mentors (supervising teachers) in schools via phone contact. The mentor's role was to facilitate their student teacher's professional growth. We encouraged a 'collaborative mentoring' approach that involved the following practices: systematic reflection, focused sharing, collaborative planning, negotiated observations, constructive feedback and learning conversations (McCann and Radford 1993). The emphasis in the final practicum subject was on the student teachers having increased autonomy and responsibility and so their role required them to be actively involved in their own learning.

The study investigated student teachers' experiences with 'email supervision'. This model of supervision required the student teachers to email their university lecturer twice throughout the practicum and make weekly contact with a peer, known as a 'critical friend'. This innovation was made possible because of two changed conditions. Firstly, the students were competent users of email, having had prior exposure to email though a core subject in the first year of their degree. In this subject students were taught how to use the University computer systems, email, discussion lists and 
netiquette. In addition to this subject, students were then expected to communicate with their lecturers and tutors via email throughout the remainder of their course. Secondly, schools in South Australia had recently been connected to the Internet in a systematic way that provided World Wide Web (WWW) and email access to all teachers and students.

The wide range of skill and comfort levels within the teaching population, together with access problems in the past, has meant that we are only now trailing email communication with the teachers. This paper therefore focuses only on student teachers' and university lecturers' experiences with email.

\section{METHODOLOGY}

The study had two stages. In 1999 a pilot study was conducted with twenty students, involving the use of focus groups. The focus groups were conducted several months after the students had completed their practicum and revolved around questions which explored student teachers' experiences with ICT in the practicum, what helped and what hindered and their perceptions of using email as a form of communication in the practicum. The focus group data were analysed and key issues were identified.

The second stage of the study focused on the 2000 cohort of 124 students who went to 84 schools for the practicum. A questionnaire, based on the issues highlighted from the focus groups and the literature, was administered to the students on completion of their practicum. The data from the questionnaires were then entered and analysed using SPSS.

\section{RESULTS AND DISCUSSION}

In the results ninety-three $(76.2 \%)$ of the student teachers surveyed regarded 'email supervision' as appropriate for the final practicum. When the reasons for this were analysed, reduction of stress was one of the key findings. It is this particular finding which is the focus of this paper. The factors that were perceived as reducing stress will be discussed under the following headings.

- Structural and cultural conditions of practicum

- Nature of electronic communication. 


\subsection{Structural and cultural conditions of practicum}

The traditional practicum experience, where student teachers spend time observing and teaching in one classroom, has been criticised in the literature, for not optimising student teacher learning (Martinez 1990, Zeichner 1980). In the past decade, many teacher educators have been involved in reconceptualising the practicum around the concepts of reflection, partnerships and collaboration. It is recognised that for practicum reform to be effective there must be a focus on both structural changes, referring to the changes to roles and responsibilities of the various participants in the practicum and cultural changes, or changes to the shared beliefs, customs, attitudes and expectations (Hargreaves 1994, Le Cornu 1999).

In this study, changes to the structural and cultural conditions of practicum were enabled by the use of electronic communications. The structural changes can best be exemplified by highlighting the perceived less threatening supervision experienced by some of the student teachers. The cultural changes can be exemplified by a perceived change in status in the school setting experienced by some of the student teachers. Each will now be briefly discussed.

\subsubsection{Less threatening than traditional university supervision}

Many of the student teachers found the 'email supervision' model utilised in the program, less threatening than the supervision they had been used to. They compared how they felt emailing their university lecturer, with their previous 'face to face' visits, where in many instances, they were observed in the classroom. The following quotes depict the anxiety associated with these visits:

"It wasn't as threatening experience as personal contact i.e. Uni. supervisors breathing down your neck."

"It was a lot more comfortable than having a Uni. supervisor 'watching' our lessons."

This finding is consistent with the claim in the literature that it is the 'act of being supervised' that causes stress (Calderhead 1988). Even with changes which have been made to supervision, from traditional models based on classroom observation to more facilitatory models which aim to develop the reflective capabilities of prospective teachers (Martinez 1990), university supervision, which requires face to face communication, continues to be problematic. Amidst the current climate of reduction in government funding, higher student-staff ratios and increased expectations 
and demands on academics' time, school visits by university staff are becoming increasingly difficult to maintain. Even when students are seen in their school by a university lecturer, conversations are often short and usually focus on immediate classroom practices and events of the day (Wentworth et al. 1999). Moreover, school environments are becoming increasingly 'busy places' and so people feel under pressure to make time available within school time, to meet. Similarly, student teachers are leading increasingly busier, more complicated lives, with many of them often juggling part-time work commitments alongside their practicum commitments. As one student described the benefits of the email process:

"Easy, quick. We had a lot to do. This was 'low stress' which was great."

The flexibility of emailing, together with the reduced stress of a face to face visit, were seen by many of the student teachers to contribute to the ease of managing their practicum. The role of student teacher as 'manager', of both the personal and professional dimensions of being a 'student teacher', is increasingly, a more demanding role. Student teachers need to be able to manage the demands of 'learning to teach' as well as their own energy and stress levels. Emailing their university lecturer, in this study, was seen to enable this process.

\subsubsection{Perceived changed status within the school setting}

Some of the student teachers in this study clearly perceived a change in status, for themselves within the school setting. Rather than seeing themselves as 'only student teachers', they saw themselves as emerging professionals. They interpreted the use of electronic communication as a way of supporting their level of maturity in the course. This point is depicted in the following:

"We are about to enter the teaching profession so it was good that we were treated that way."

"Shows we can be trusted. It was made our responsibility."

Not only did the student teachers perceive themselves differently, but a number reported a different relationship they experienced with their mentor and other school staff, as they too perceived them differently. Several student teachers reported examples where they had been publicly cited as 'colleagues', particularly where they had been seen to make a contribution to the school environment. A relevant example of this was related to the students' competency in the use of technology, where they were able to provide assistance and in-service training on the use of ICT. This perceived 
change in status is important, given what we know about the micro-politics of the practicum, where issues of status and power impact on both student teacher learning and their stress levels (Groundwater-Smith 1993).

While student teachers will always encounter a range of confusing and often contradictory messages about their position in a school, how we, as university teacher educators interact with our students 'in the field', can affect the level of stress experienced by them.

\subsection{Nature of electronic communication}

Much has been reported in the literature about the benefits of asynchronous electronic communication (Everett and Ahern 1994, Jonassen 1996) and this was also evident in the data collected in this study. Email enabled both lecturer and student teacher to contribute to professional discussions at various times convenient to them. Some student teachers were able to utilise non-teaching time in schools to access a computer and email their university lecturer, while others chose to do it from home after the school day had finished. In terms of access almost half of the students (45.1\%) used email from home, with $31.1 \%$ accessing from their school setting, with the remainder of the students accessing from other unnamed locations. Access was rated as 'easy' or 'very easy' by $88.9 \%$ of the students with only five students (4.3\%) rating it as 'very difficult'.

"The flexibility and ease of access afforded by the use of email is reflected in the following:"

"It is often difficult to arrange a time to meet people while teaching at school. It is much easier to email."

The students had varying perceptions of the emailing process with the majority of students identifying it as a written communication (65.8\%), and more than half the students $(71.3 \%)$ proof reading their email before they sent it. The comments indicated that these students saw it more as a formal 'professional' process and allowed them time to construct their response. For example:

"Writing is different to speaking. Good to have 'professional' and 'independent' dialogue."

"I was able to sit down on the weekend and really think about what I would write rather than just babble on the phone. It was useful for me to reflect on the week and be quite open about what I wrote. I definitely prefer written contact than oral/verbal." 
However a small number likened email to the spoken word and regarded it as a much less formal process. This was exemplified in the following:

"Email is a verbal form of communication, and it was like speaking personally of successes and failures. It was less formal than a written response, which allowed honesty and reflection."

"As I saw it as a verbal mode of communication, I was able to really engage."

From these results it can be seen that regardless of the students' perception of the nature of email, they were able to engage with the medium.

In the second stage of the study guiding questions were provided to the student teachers to assist them when communicating with their lecturers. This overcame a concern that had emerged in the stage 1 focus groups in regard to what to write in their emails. The results showed that $90 \%$ of the students found these questions very useful in structuring their email responses. Their written comments supported this finding, as exemplified by:

"It encouraged me to identify areas of significance, and critically reflect on these."

This is consistent with the work of Geer and $\mathrm{Au}$ (1998) who also found that while email has the potential to increase interaction and encourage a deeper understanding of the subject matter it needs to be supported.

Engaging in 'learning conversations' has been found to be of use both in the learning to teach process, and in ongoing teacher development (McLaughlin 1997). Opportunities for these conversations were structured into the design of the email supervision process described in this paper. The students were asked to rate the effectiveness of the dialogue with their mentor, critical friend and the university lecturer, on a scale of 1 to 5 where 1 was 'ineffective' and 5 was 'very effective'.

Table 1. Dialogue Effectiveness

\begin{tabular}{|l|r|r|}
\hline & Mean & Std. Deviation \\
\hline & & .7421 \\
\hline Dialogue with my mentor & 4.5084 & .8611 \\
\hline Dialogue with my critical friend & 4.1780 & 1.0245 \\
\hline Email dialogue with my workshop lecturer & 3.9957 & \\
\hline
\end{tabular}

From Table 1 it can be seen that students found all three sources of dialogue useful in terms of their learning. The most useful dialogue identified by the students was not surprisingly with their mentor, but the level of satisfaction with both their critical friend and their university lecturer was still very high. 


\section{CONCLUSION}

While we are not advocating 'email supervision' for all students in all practicums, this study has shown that email can be used effectively by university teacher educators to facilitate less stressful practicum experiences for student teachers. There will always be an element of stress for student teachers in relation to the practicum because of its very nature, however ICT has the potential to give more control over the learning process to the student teachers and therefore enable them to manage their practicum experience more effectively.

The students in this study clearly valued the email dialogue they had with their university lecturer during the practicum. This confirms the importance of the university lecturer's role in practicum, but at the same time challenges the established and often romanticised views of the value of face-to-face university supervision which, of economic necessity as mentioned earlier, has decreased in frequency and quality over the last years.

\section{REFERENCES}

Britzman, D. P. (1991) Practice makes practice: A critical study oflearning to teach. State University of New York Press, Albany NY.

Calderhead, J. (1988) The Contribution of Field Experiences to Student Primary Teachers' Professional Learning. Research in Education, 40, pp. 33-49.

Everett, D. R. and Ahern, T. C. (1994) Computer-mediated communication as a teaching tool: A case study. Journal of Research on Computing in Education, 26 (3), pp. 356-357.

Geer, R. and Au, W. (1998) Electronic mail and student learning. In Where is IT \& Tat? ACEC 98 Refereed Conference Proceedings, CEGSA, Adelaide, pp. 76-81.

Groundwater-Smith, S. (1993) The micro-politics of the practicum: A critical issue. In Learning in the Field: The Current Face of Practical Experiences in Professional Preparation, Post Conference Publication of the 5th National Practicum Conference, Macquarie University, Sydney.

Hargreaves, A. (1994) Restructuring - beyond collaboration. In Changing Teachers, Changing Times: Teachers' Work and Culture in the Postmodern Age, Cassell, London.

Jonassen, D. H. (1996) Computers in the classroom: Mindtools for critical thinking. Prentice Hall, New Jersey.

Le Cornu, R. (1999) Remapping the Practicum in Teacher Education. Waikato Journal of Education, 5, pp. 121-132.

Martinez, K. (1990) Critical Reflections on Critical Reflection in Teacher Education. The Journal of Teaching Practice, 10 (2), pp. 20-28.

McCann, I. and Radford, R. (1993) Mentoring for Teachers: the collaborative approach. In The Return of the Mentor, B. Caldwell and E. Carter (eds.), Falmer Press, London, pp. 2543.

McLaughlin, M. (1997) Rebuilding Teacher Professionalism in the United States. In Beyond Educational Reform: Bringing Teachers Back In, A. Hargreaves and R. Evans (eds.), Open University Press, Buckingham. 
Schlagal, B., Trathen, W. and Blanton, W. (1996) Structuring telecommunications to create instructional conversations about student teaching. Journal of Teacher Education, 47 (3), pp. 175-183.

Wentworth, N., Monroe, E., Orme, M. and Lynes, B. (1999) Enriching Preservice Field Experience through Email Mentoring. In Society of Information Technology in Teacher Education, Conference Proceedings.

Zeichner, K. (1980) Myths and Realities: Field Experiences in Preservice Teacher Education. Journal of Teacher Education, 31 (6), pp. 45-55.

\section{BIOGRAPHY}

Bruce White and Rosie Le Cornu are lecturers at the University of South Australia, involved in preservice $\mathrm{K}-12$ teacher education. Their current research includes ways that ICT can be used to develop a learning community to support student in the practicum. 